\title{
Effect of propionic and lactic acids on in vitro ruminal bacteria growth
}

\author{
Juliana Silva de Oliveira ${ }^{1}$, Augusto César de Queiroz ${ }^{2}$, Hilário Cuquetto Mantovani², Marcelo \\ Rodrigues de Melo², Edenio Detmann ${ }^{2}$, Edson Mauro Santos ${ }^{1}$, Geraldo Fábio Viana Bayão ${ }^{2}$ \\ 1 UFPB - Universidade Federal da Paraíba. \\ 2 UFV - Universidade Federal de Viçosa.
}

ABSTRACT - The objective of this work was to evaluate the effect of the levels of lactic and propionic acids on in vitro fermentation of ruminal microorganisms. In experiment 1 , the levels, in a total of 12 were the following: addition of 0 (control 1), 50, 100, 150, 200 and $250 \mathrm{mM}$ of lactic acid and 0 (control 2), 50, 100, 150, 200 and $250 \mathrm{mM}$ of propionic acid, respectively, in incubation flasks, which contained ruminal inoculum, glucose and synthetic culture medium, with two repetitions for each combination. In experiment 2, the combinations, in a total of 4, were the following: presence of 12 and $24 \mathrm{mM}$ of propionic acid and $0 \mathrm{mg}$ of glucose, respectively; presence of 12 and $24 \mathrm{mM}$ of propionic acid and $40 \mathrm{mg}$ of glucose, respectively, to the incubation flasks which contained ruminal inoculum, with or without glucose and in synthetic culture medium with two repetitions each. There was no effect on the specific growth velocity of ruminal microorganisms in the presence of lactic acid or propionic acid. However, when there were greater concentrations of these acids in the media, there was a longer lag phase in the microorganism phase. Acid propionic at the concentration of $24 \mathrm{mM}$ inhibited the production of acid acetic and butyric acid in a media with glucose. Despite of not being used as a source of energy by the ruminal microorganisms, propionic acid affects their metabolism. Lactic and propionic acids inhibit growth of some rumina microorganisms at elevated concentrations.

Key Words: lactate, food additive, propionate, ruminal manipulation

\section{Efeito dos ácidos láctico e propiônico sobre o crescimento de bactérias ruminais in vitro}

\begin{abstract}
RESUMO - Objetivou-se com este trabalho avaliar o efeito de níveis de ácido láctico e do ácido propiônico sobre a fermentação de microrganismos ruminais in vitro. No experimento 1, os níveis, em um total de 12, foram os seguintes: adição de 0 (controle 1), 50, 100, 150, 200 e 250 mM de ácido láctico e 0 (controle 2), 50, 100, 150, 200, 250 mM de ácido propiônico, respectivamente, aos tubos de incubação, que continham inóculo ruminal, glicose e meio de cultura sintético, com duas repetições para cada combinação. No Experimento 2, as combinações, em um total de 4, foram os seguintes: presença de 12 e $24 \mathrm{mM}$ de ácido propiônico e $0 \mathrm{mg}$ glicose, respectivamente; presença 12 e $24 \mathrm{mM}$ de ácido propiônico e $40 \mathrm{mg}$ glicose, respectivamente, aos tubos de incubação que continham inóculo ruminal, com ou sem glicose e meio de cultura sintético com duas repetições cada. Não houve efeito na velocidade específica de crescimento dos microrganismos ruminais na presença de ácido láctico ou propiônico. Entretanto, quando nos meios havia concentrações maiores desses ácidos, houve maior fase lag no crescimento dos microrganismos. A concentração de $24 \mathrm{mM}$ de ácido propiônico inibiu a produção de ácido acético e ácido butírico em meio com glicose. Apesar de não ser usado como fonte de energia pelos microrganismos ruminais, o ácido propiônico afeta seu metabolismo. Os ácidos láctico e propiônico, em concentrações elevadas, inibem o crescimento de determinados microrganismos ruminais.
\end{abstract}

Palavras-chave: aditivos alimentares, lactato, manipulação ruminal, propionato

\section{Introduction}

The rumen is considered an open and continuous environment, which provides an ideal environment for maintenance of stable microbial communities coming from the evolution of millions of years of selection. However, this ecosystem can be manipulated to improve the use of substrate and the efficiency of food fermentation (Bello \& Escobar, 1997) to improve animal performance. Thus, there is an interest in the effects of different compounds on ruminal fermentation (Martin, 1998).

Among the ruminal manipulators studied for ruminants, organic acids have been highlighted. Organic acids are carboxylic acids which are commonly found in biological 
tissues. Those acids are in the list of food additives authorized by the European legislation in use for all ruminant species, because they do not leave residuals in animal origin products (Castillo et al., 2004).

Organic acids act in the rumen preventing the drop of ruminal $\mathrm{pH}$ and reducing methanogenesis (Castilo et al., 2004). Thus, in the rumen, those acids can stimulate ruminal growth of prominent bacteria and consequently change favorably ruminal fermentation, improving ruminant performance (Martin, 1998).

The objective of this work was to evaluate the effect of propionic and lactic acid on in vitro ruminal microorganism growth.

\section{Material and Methods}

Two experiments were carried out to clarify the isolate effect of lactic and propionic acid on ruminal microorganisms. Both in vitro experiments were performed in Laboratório de Microbiologia de Anaeróbicos in the Departamento de Microbiologia at Universidade Federal de Viçosa - UFV, in Viçosa, Minas Gerais.

It was used as a rumen liquid donor a steer fistulated in the rumen, grazing Brachiaria decumbens grass pasture. The steer was housed in the Laboratório de Animais in the Departmento de Zootecnia of UFV.

In the first experiment, one litter of the ruminal liquid was collected from the rumen-fistulated steer and immediately taken to the laboratory in a thermal container. Then, it was put in rest for 30 minutes at $39^{\circ} \mathrm{C}$. After formation of liquid interfaces, the intermediate liquid was withdrawn, centrifuged at $5000 \mathrm{x}$ g for 10 minutes and the supernatant was discarded for obtaining the inoculum containing active microbial population (pellet) (Melo, 2007). The formed pellet, which contained microorganisms predominantly in the ruminal liquid, was re-suspended in saline solution $0.9 \%$ autoclaved and saturated with carbon dioxide. It was proceeded a new centrifugation at 5,000 x g for 10 minutes and the supernatant was again discarded. The pellet formed in the last centrifugation was re-suspended in an autoclaved saline solution $0.9 \%$ and saturated with carbon dioxide (inoculum), and the same inoculum was used in all experimental units (Melo, 2007).

It was used a complete random design, in a $2 \times 6$ factorial arrangement (two acids and six concentrations of each acid) with two replicates. The concentrations were the following: 0 (control 1), 50, 100, 150, 200, and $250 \mathrm{mM}$ of lactic acid, respectively and 0 (control 2) 50, 100, 150, 200, and $250 \mathrm{mM}$ of propionic acid.
The experiment was performed in two non-simultaneous steps: the first one with lactic acid and the second one with propionic acid. All incubation flasks contained $0.2 \mathrm{~mL}$ of inoculum, $40 \mathrm{mg}$ of glucose, and synthetic culture media (40 mL of A saline solution - which contained per litter: $7.3 \mathrm{~g}$ of $\mathrm{K}_{2} \mathrm{HPO}_{4} * 3 \mathrm{H}_{2} \mathrm{O} ; 40 \mathrm{~mL}$ of saline solution $\mathrm{B}$ - which contained per litter: $6.0 \mathrm{~g}$ of $\mathrm{K}_{2} \mathrm{HPO}_{4}, 12.0 \mathrm{~g}$ of $\left(\mathrm{NH}_{4}\right)_{2} \mathrm{SO}_{4}$, $12.0 \mathrm{~g}$ of $\mathrm{NaCl}, 2.5 \mathrm{~g}$ of $\mathrm{MgSO}_{4} * 7 \mathrm{H}_{2} \mathrm{O}$ and $1.6 \mathrm{~g}$ of CaCl$* 2 \mathrm{H}_{2} \mathrm{O}$; $0.50 \mathrm{~g}$ of yeast extract; $1.0 \mathrm{~g}$ of trypticase - Trypticase, BBL Microbiology Systems, Cockesyille, MD; $0.60 \mathrm{~g}$ of cysteine hydrochloride; $1.0 \mathrm{~mL}$ of resazurin; $4.0 \mathrm{~g}$ of sodium carbonate; and $870 \mathrm{~mL}$ of water autoclaved and saturated with carbon dioxide at the quantities needed to reach $10 \mathrm{~mL}$ of medium in the total at all levels. Lactic and propionic acid were diluted separately and added to reach the determined final concentrations in the culture medium of each level. Incubations were done in anaerobic flasks, in which the medium was saturated with carbon dioxide; the flasks were sealed and kept at $39^{\circ} \mathrm{C}$.

Initial optical density (time zero) of each experimental unit was measured in the own anaerobic flasks, in a Spectronic 20D+ (Thermo Electron, Waltham, MA, USA) spectrophotomer with a wave length of $600 \mathrm{~nm}\left(\mathrm{DO}_{600 \mathrm{~nm}}\right)$. The other reading times were determined by velocity of microorganism growth in each concentration of the acids. After stabilization of microbial growth (values identical of the optical density three consecutive times), incubation was finished.

Growth specific velocity $(\mu)$ of each level was calculated from the linear phase of the neperian exponential graph of $\mathrm{DO}_{600 \mathrm{~nm}}$, in which $\mu$ is the absolute constant rate with the unit in $\mathrm{h}^{-1}$ :

$$
\operatorname{Ln} \mathrm{N}=\mu t+\operatorname{Ln} \mathrm{N}_{0}
$$

in which: $\operatorname{Ln} \mathrm{N}$ = intercept on ordinate axis; $\mathrm{t}=$ time abscissa; and $\operatorname{Ln} \mathrm{N}_{0}=$ intercept on abscissas axis.

Maximal optical density corresponded to the reading of optical density when cell growth was ceased and the culture entered in the stationary phase.

The lag phase corresponded to time elapsed before exponential growth observed in the graph.

Data were submitted to analysis of variance and the means were compared by the Tukey test $(\alpha=0.05)$.

In the second experiment, one litter of ruminal liquid was collected from a rumen-fistulated steer and immediately taken to the laboratory in a thermal container. For preparation of the inoculum, the same procedures taken for the first experiment were adopted. The pellet formed in the last centrifugation was then re-suspended in a synthetic culture medium autoclaved and saturated with carbon dioxide (cells), 
and the same inoculum was used in all experimental units (Melo, 2007).

It was used a complete randomized design, in a $2 \times 2$ (two concentrations of propionic acid and two levels of glucose) factorial arrangement, with three replicates each. The combinations were the following: : Presence of 12 and $24 \mathrm{mM}$ of propionic acid and $0 \mathrm{mg}$ of glucose, respectively (combinations 1 and 2) and presence of $12 \mathrm{mM}$ and $24 \mathrm{mM}$ of propionic acid and $40 \mathrm{mg}$ of glucose, respectively (combinations 3 and 4).

The culture media were prepared from the ruminal liquid centrifuged and re-suspended in synthetic culture medium (cells). Incubation flasks contained $9.6 \mathrm{~mL}$ of cells, $40 \mathrm{mg}$ of glucose at the combinations 3 and 4 , and pure synthetic culture mediums at quantities needed to reach $10 \mathrm{~mL}$ of medium at total in all combinations. Propionic acid was added to reach $12 \mathrm{mM}$ in the final concentration in combinations 1 and 3 and $24 \mathrm{mM}$ in the final concentrations 2 and 4 . Incubations were done in anaerobic flasks, in which the medium was saturated with carbon dioxide, the flasks were sealed and kept at $39^{\circ} \mathrm{C}$ for 48 hours.

Samples of the culture media were collected at times 0, 6, 12, 24 and 48 hours, placed in eppendorf flasks and centrifuged at $5200 \mathrm{x} g$, for 10 minutes. The supernatant was frozen for analysis of concentration of propionic acid, acetic acid, butyric acid and lactic acid by high performance liquid chromatography - HPLC. To do so, it was used a chromatograph Hewlett-Pacckard series 1050 coupled to a refractive index detector (IR) Hewlett-Pacckard 1047A
(Hewlett-Pacckard Company, Wilmington, DE, USA), kept at $45^{\circ} \mathrm{C}$, and column Bio-Rad HPX-87H, $300 \times 7.8 \mathrm{~mm}$ (Bio-Rad Laboratories, Hercules, CA) kept at $60^{\circ} \mathrm{C}$. The $\mathrm{pH}$ of each experimental unit was read by using a potentiometer after 48 hours of incubation.

Data were submitted to analyses of variance, and the means were compared by the Tukey test $(\alpha=0.05)$.

\section{Results and Discussion}

It was not observed any effect of lactic acid or propionic acid on specific velocity of microorganism growth (Table 1 ).

However, there were effect of the acid and of concentrations of the acids on the maximum optic density $\left(\mathrm{DO}_{600 \mathrm{~nm}}\right)$ and lag phase (Table 2). Acid lactic at $200 \mathrm{mM}$ in the medium provided more optical density than $200 \mathrm{mM}$ of propionic acid. When concentrations of the acids were increased to $250 \mathrm{mM}$, this situation was inverted and $250 \mathrm{mM}$ of propionic acid provided greater maximum optical density than $250 \mathrm{mM}$ of lactic acid. The medium with greater concentration of lactic acid $(250 \mathrm{mM})$ was reduced to $\mathrm{DO}_{600 \mathrm{~nm}}$ when compared to the control level and to lower levels of lactic acid (50, 100, 150 and $200 \mathrm{mM})$ in the medium. There was no effect of propionic acid concentrations in the medium on $\mathrm{DO}_{600 \mathrm{~nm}}$.

The stage with propionic acid in the medium provided longer lag phase (5.5 hours) when compared to the stage which contained lactic acid in the medium (4.0 hours). At the concentrations of 0,50 and $100 \mathrm{mM}$ of lactic acid, there was

Table 1 - Mean values of specific velocity of microorganism growth $(\mu)$ of mixed culture of ruminal bacteria at different concentrations of lactic acid and propionic acid

\begin{tabular}{|c|c|c|c|c|c|c|}
\hline \multirow{2}{*}{$\begin{array}{c}\text { Acid } \\
\mu \\
\end{array}$} & \multicolumn{3}{|c|}{ Lactic acid } & \multicolumn{3}{|c|}{ Propionic acid } \\
\hline & \multicolumn{3}{|c|}{1.0542} & \multicolumn{3}{|c|}{1.0417} \\
\hline Concentrations (mM) & 0 & 50 & 100 & 150 & 200 & 250 \\
\hline
\end{tabular}

Table 2 - Mean values of maximum optical density (maximum $\mathrm{DO}_{600 \mathrm{~nm}}$ ) and lag phase of ruminal bacteria mixed culture at different concentrations of lactic acid and propionic acid

\begin{tabular}{|c|c|c|c|c|c|c|}
\hline \multirow[t]{2}{*}{ Concentration $(\mathrm{mM})$} & \multicolumn{6}{|c|}{ Maximum $\mathrm{DO}_{600 \mathrm{~nm}}$} \\
\hline & 0 & 50 & 100 & 150 & 200 & 250 \\
\hline Lactic acid & $2.0900 \mathrm{aA}$ & $2.1100 \mathrm{aA}$ & $2.2550 \mathrm{aA}$ & $2.2200 \mathrm{aA}$ & $2.3250 \mathrm{aA}$ & $1.5600 \mathrm{bB}$ \\
\hline Propionic acid & $2.2800 \mathrm{aA}$ & $2.2900 \mathrm{aA}$ & $2.1300 \mathrm{aA}$ & $2.2700 \mathrm{aA}$ & $2.0200 \mathrm{aB}$ & $2.2050 \mathrm{aA}$ \\
\hline \multirow[t]{2}{*}{ CV (\%) } & 4.65 & & & & & \\
\hline & \multicolumn{6}{|c|}{ Lag phase (hours) } \\
\hline Lactic acid & $3.0 \mathrm{cB}$ & $3.0 \mathrm{cB}$ & $3.0 \mathrm{cB}$ & $3.5 \mathrm{bB}$ & $4.0 \mathrm{aB}$ & $4.0 \mathrm{aB}$ \\
\hline Propionic acid & $4.0 \mathrm{dA}$ & $4.0 \mathrm{dA}$ & $4.5 \mathrm{cA}$ & $5.0 \mathrm{bA}$ & $5.0 \mathrm{bA}$ & $5.5 \mathrm{aA}$ \\
\hline CV (\%) & 0.50 & & & & & \\
\hline
\end{tabular}

Means followed by lower case letters in the lines and capital letters in the columns differ $(\mathrm{P}<0.05)$ by Tukey test. 
no difference in the lag phase (3.0 hours). From $150 \mathrm{mM}$ of lactic acid, lag phase increased with the increase of concentration of lactic acid in the media, stabilizing at $200 \mathrm{mM}$ of acid (4.0 hours). The same occurred with propionic acid, in which the increase in the concentration of this acid, from $100 \mathrm{mM}$, provided longer phase lag, reaching the longest lag phase at the concentration of $250 \mathrm{mM}$ of propionic acid in the medium (5.5 hours).

A smaller microbial growth was observed when $250 \mathrm{mM}$ of lactic acid were added into the media. These results demonstrate that high concentrations of acid lactic inhibit growth of many ruminal bacteria group. The same did not occur at different concentrations of propionic acid in the media, where concentrations up to $250 \mathrm{mM}$ of propionic acid did not cause a reduction in the concentration of ruminal microorganisms in the media, it only delayed its growth from $100 \mathrm{mM}$.

Many species of bacteria in the rumen produce lactic acid in a pure culture, but the concentration of this in vivo organic acid is usually lower than $1 \mathrm{mM}$ (Hobson \& Sterwart, 1997). This happens because other lactic acid fermenting bacteria, as for example Veilonella alcalescens, Megasphaera elsdenii and Selenomonas ruminantium, avoid that acid lactic accumulates in the rumen.

Acid lactic is a strong acid and its accumulation might cause a pronounced $\mathrm{pH}$ drop, inhibiting synthesis of microbial protein (Russell, 2002; Martin, 1998; Lana et al., 1998). Therefore, concentrations of $250 \mathrm{mM}$ of lactic acid could have inhibited ruminal microorganisms sensitive to low pH. Russel \& Hino (1985) observed that, when extracellular pH decreases, intracellular $\mathrm{pH}$ also decreases. Cell membrane of microorganisms in the rumen does not allow the passive entry of protons $\left(\mathrm{H}^{+}\right)$neither of hydroxyl $\left(\mathrm{OH}^{-}\right)$but it allows other molecules, as acid lactic in the nondissociated form to enter in the cell (Russel \& Hino, 1985). When lactic acid crosses the plasmatic membrane, it dissociates in the cell cytoplasm releasing a proton and acidifying intracellular $\mathrm{pH}$, which results in an ATP expenditure in the attempt of the cell to reestablish homeostasis in the cytoplasm (Owens et al., 1993). This process compromises fermentation of substrates by the cell and consequently the microbial growth.

Ruminal bacteria present different sensitivities to $\mathrm{pH}$. Cellulosic bacteria constitute one of the most sensitivity group to $\mathrm{pH}$ drop in the media, which inhibits their growth (Russell \& Strobel, 1989). Other groups sensitive to $\mathrm{pH}$ drop are the different population of ammonia producer bacteria (Lana et al., 1998). Many other bacteria are also sensitive to $\mathrm{pH}$ drop, decreasing fermentation of hexoses in low $\mathrm{pH}$ and deviating ATP from growth to non-growth functions
(Russell \& Strobel, 1989). Possibly in the media with lower concentrations of lactic acid (50, 100, 150 and $200 \mathrm{mM})$, ruminal microorganisms were able to use this acid as a substrate, avoiding that accumulation of lactic acid inhibited the other ruminal microorganisms. Attenuation of effect of intracellular acid when there is acid lactic in the media was also observed by Russel \& Hino (1985) in a media growing Streptococcus bovis. In this experiment, for example, concentrations equal to and lower than $200 \mathrm{mM}$ of this acid in the medium could have not interfered in the growth of microorganisms sensitive to low $\mathrm{pH}$. When there was $250 \mathrm{mM}$ in the medium, acid could have inhibited low $\mathrm{pH}$ sensitive bacteria, providing a lower concentration of microorganisms in the medium, which could have been observed by the lower maximum optical density at this concentration.

Propionic acid delayed microbial growth from $100 \mathrm{mM}$, what could have been seen because of the longer lag phase. However, there was no effect of this acid on the final concentration of ruminal microorganisms. This effect could have happened because this acid, at levels greater than $100 \mathrm{mM}$ inhibit part of the population of ruminal bacteria, favoring only bacteria resistant to high concentrations of it, bacteria which have growth rate rather slow with longer lag phase. Bello \& Escobar (1997) verified that the increase of propionate in the medium promotes a selective effect on the group of bacteria. This could have been confirmed by the second experiment, in which there was a modification of the profile of fermentation of the microorganisms in the rumen when different concentrations of the propionic acid were present in the medium (Figure 1).

According to Owens et al. (1993), propionate and butyric only reduce microbial multiplication when their concentration considerably overpass physiological levels. Overall, concentration of propionic acid in the rumen is $30 \mathrm{mM}$, taking into account data of concentration mean of total volatile fatty acids in the rumen and the molar percentage of ruminal propionic acid (Dijkstra et al., 2005). Concentrations of propionic acid (50, 100, 150, 200 and $250 \mathrm{mM}$ ) tested in this work were greater than the ones usually existing in the rumen, which are able to inhibit ruminal microorganisms in in vitro experiments in a close system.

Probably, the microorganisms resistant to high concentrations of propionic acid presented slower growth but they reached the same maximum optical density in the medium of microorganisms contained at the control level (Table 2), demonstrating that propionic acid did not impend them to growth.

Because it is a product from fermentation, as lactic acid, propionic acid has the capacity to migrate in the nondissociate form into the cell. Thus, propionic acid at high 

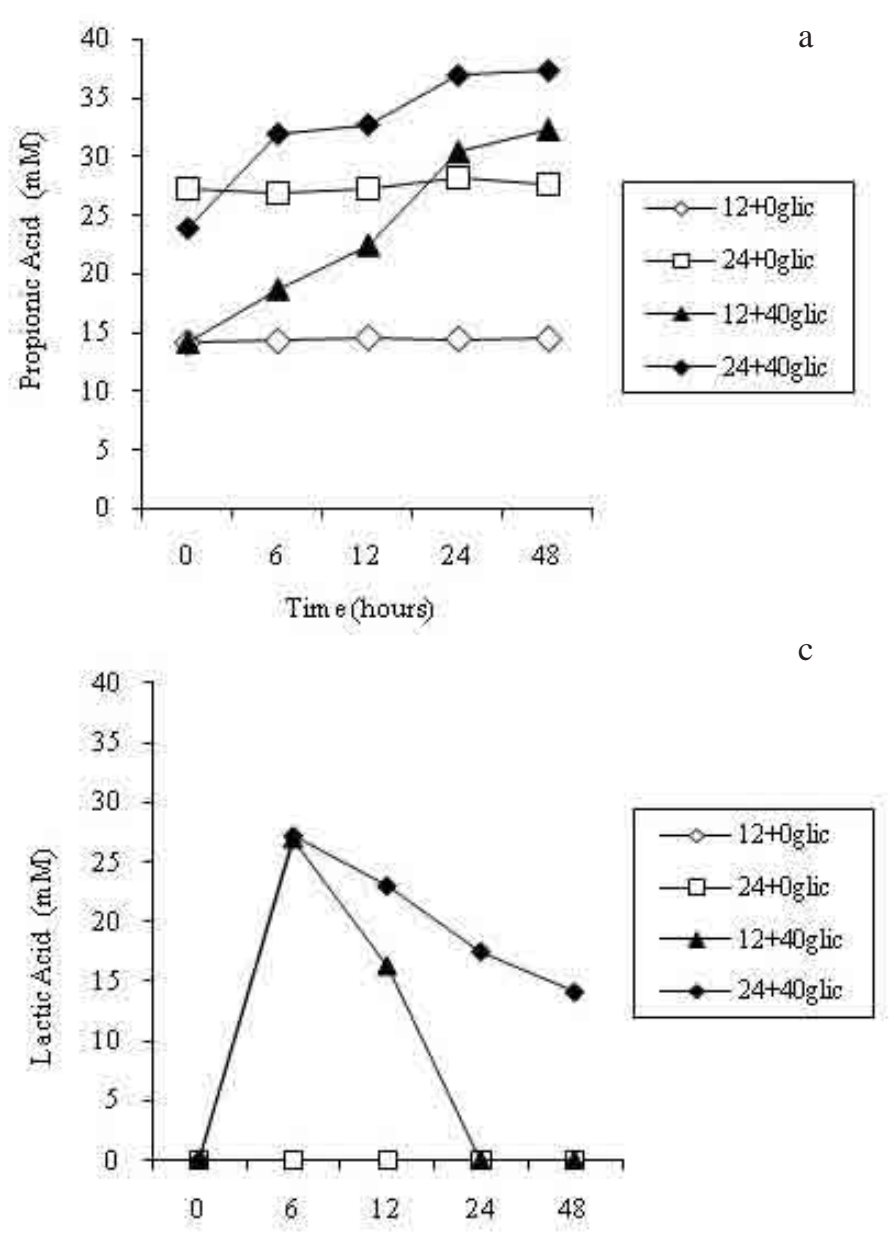

Time (hours)

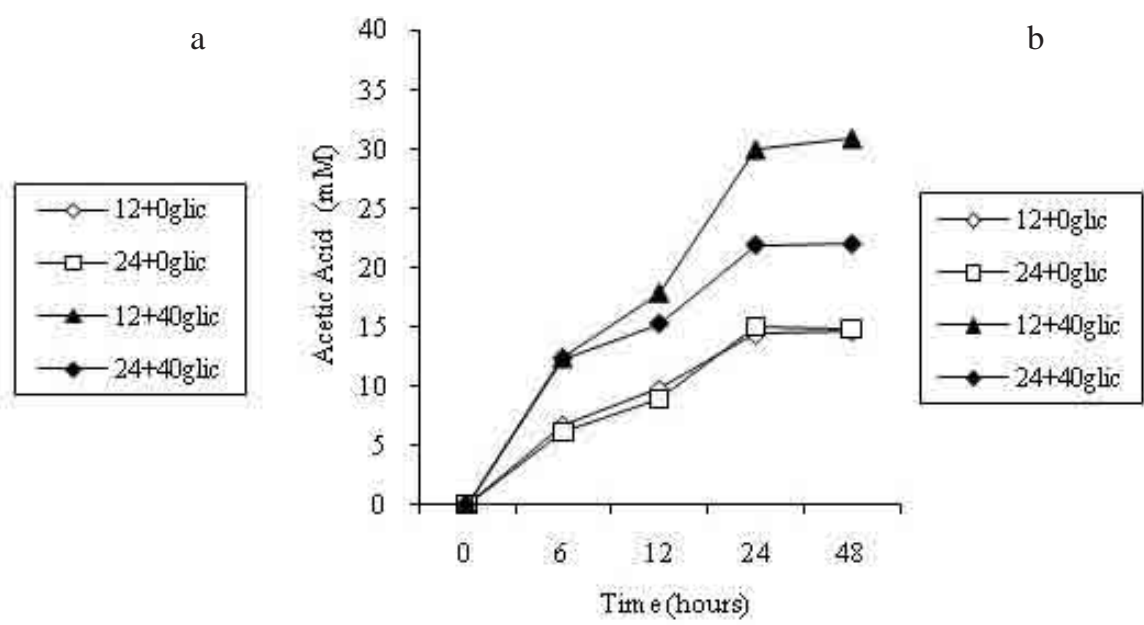

d

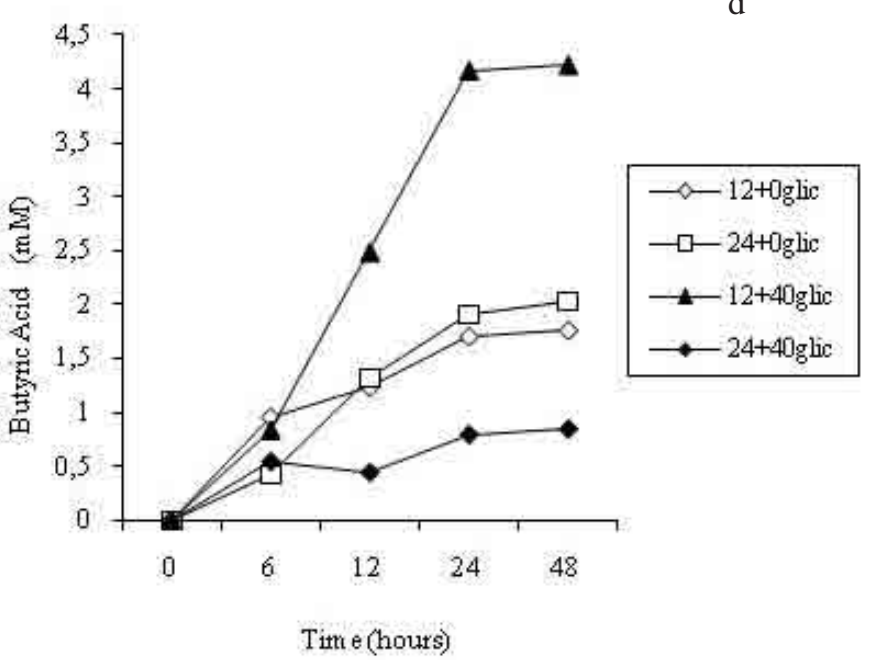

Rumen bacteria grown in a basal medium with different concentrations of propionic acid (Prop) and glucose (Glic) (12+0 glic $=12 \mathrm{mM}$ of Prop and 0 mg of glucose; $24+0$ glic $=24 \mathrm{mM}$ of Prop and $0 \mathrm{mg}$ of glucose; $12+40$ glic $=12 \mathrm{mM}$ of Prop and $40 \mathrm{mg}$ of glucose; and $24+40$ glic $=24 \mathrm{mM}$ of Prop and $40 \mathrm{mg}$ of glucose).

Figure 1 - Concentrations of propionic acid (a), acetic acid (b), lactic acid (c) and butyric acid (d) over time in a medium with ruminal bacteria.

concentrations in the medium can act similarly to lactic acid, by reducing the bacteria intracellular $\mathrm{pH}$. According to Webel et al. (2005), pH inhibits or decreases cell growth of some bacteria whereas others more adapted to low $\mathrm{pH}$ proliferates.

Although lactic acid as well as propionic acid inhibits ruminal microbial growth, their inhibition power differs from each other. Propionic acid provided lower inhibition than lactic acid did, probably because it provides small pH drop when added at concentrations similar to lactic acid. Priego \& Sutherland (1977) verified that propionic acid has small effect on ruminal $\mathrm{pH}$.

It is verified by these results that propionic acid, and mainly lactic acid at high concentrations inhibit growth of some species of ruminal bacteria.

Propionic acid was not metabolized by ruminal microorganisms, regardless to its concentration in the medium and to the presence or to the absence of glucose (Figure 1a; Table 3). This can be visualized by the maintenance (12 $\mathrm{mM}$ and $24 \mathrm{mM}$ ) or by the increase of concentration of propionic acid (12 + gluc and $24+$ gluc) in the medium during the 48 incubation hours. When glucose was the source of energy in the medium, it was observed an increase in the concentration of propionic acid over time inasmuch as the microorganisms used glucose from the medium to produce propionic acid. Therefore, the greater the concentration of glucose in the medium, the greater was the production of propionic acid.

When there was no glucose in the medium, production of acetic acid during incubation was similar in the media which contained 12 and $24 \mathrm{mM}$ of propionic acid. In the media with glucose, production of acetic acid was greater in the medium which did not contain this sugar. Medium with glucose and $12 \mathrm{mM}$ of propionic acid presented greater 
Table 3 - Mean values of the concentrations of propionic acid, acetic acid, lactic acid, butyric acid and pH in media with ruminal bacteria

\begin{tabular}{|c|c|c|c|c|c|}
\hline \multirow[t]{2}{*}{ Concentration (mM) } & \multicolumn{4}{|c|}{ Basal medium } & \multirow[t]{2}{*}{ CV (\%) } \\
\hline & $12+0$ glic & $24+0$ glic & $12+40$ glic & $24+40$ glic & \\
\hline Propionic acid & $14.382 \mathrm{~d}$ & $23.574 c$ & $27.448 b$ & $32.566 a$ & 7.62 \\
\hline Acetic acid & $9.121 \mathrm{c}$ & $8.974 \mathrm{c}$ & $18.235 \mathrm{a}$ & $14.296 b$ & 16.44 \\
\hline Lactic acid & $0.000 \mathrm{c}$ & $0.000 \mathrm{c}$ & $8.631 b$ & $16.369 a$ & 63.31 \\
\hline Butyric acid & $1.128 \mathrm{~b}$ & $1.135 b$ & $2.345 a$ & $0.526 \mathrm{c}$ & 25.13 \\
\hline $\mathrm{pH}$ & $6.21 \mathrm{a}$ & $6.05 a$ & $5.72 \mathrm{ab}$ & $5.27 \mathrm{~b}$ & 3.97 \\
\hline
\end{tabular}

production of acetic acid in comparison to the medium which contained glucose and $24 \mathrm{mM}$ of propionic acid. Concentration of $24 \mathrm{mM}$ of propionic acid seems to have inhibited production of acetic acid in a medium with glucose (Figure 1b; Table 3).

Production of butyric acid was also affected by concentration of propionic acid in the medium. Concentration of $24 \mathrm{mM}$ of propionic acid in the medium which contained glucose inhibited production of butyric acid (Figure 1d; Table 3).

In the media which did not contain glucose, it was not detected lactic acid in the supernatant of the cultures (Table 3). In the glucose media, there was production of lactic acid during six hours of incubation. However, after six hours of incubation, there was a drop in the concentration of lactic acid in the medium, which was more abrupt in the medium with concentration of $12 \mathrm{mM}$ of propionic acid (Figure 1c; Table 3). Drop on concentration of lactic acid is due to the use of this organic acid by ruminal microorganisms and to its conversion into other products.

Concentration of $24 \mathrm{mM}$ of propionic acid in the medium which contained glucose provided lower $\mathrm{pH}$ in relation to the absence of glucose in the medium (Table 3).

Ruminal fermentation is an exergonic process which converts fermentable raw-material into volatile fatty acids, methane, ammonia and occasionally, lactic acid (Kozloski, 2002). Part of the released energy is used for microbial growth over these reactions. Concentrations of $24 \mathrm{mM}$ of propionic acid in basal medium containing glucose as source of carbon provided lower production of acetic acid and butyric acid over time in comparison to the medium which contained $12 \mathrm{mM}$ of propionic acid. Therefore, lower concentrations of volatile acids as acetic acid and butyric acid could be the response of the lower fermentation activity and consequently of the energy production for the bacterial cell and lower microbial growth. So, propionic acid maybe acts on some strains of ruminal bacteria modifying their cell metabolism through the ph drop in the medium. At the highest concentrations of propionic acid in the medium, there was a delay on microbial growth (Table 2), a lower $\mathrm{pH}$
(Table 3) and lower production of acetic acid and butyric acid (Figure 1b, d; Table 3).

Lactic acid can be used by some ruminal bacteria for energy production (Russell, 2002). In the media with the presence of glucose, after six hours of incubation, concentration of lactic acid in the medium gradually reduced possibly due to the fermentation of lactic acid by bacteria which ferment this acid. In the medium in which concentration of propionic acid was $12 \mathrm{mM}$, all lactic acid was fermented, which did not happen in the medium with concentration of $24 \mathrm{mM}$ of propionic acid (Figure 1c). Concentration of $24 \mathrm{mM}$ of propionic acid in the medium could have inhibited bacteria which fermented lactic acid, and the accumulation of lactic acid in the medium could have affected the metabolism of ruminal bacteria even more.

Moreover, bacteria which used lactic acid has the capacity to avoid accumulation of this acid in the medium (Figure 1c). This confirms that ruminal microorganisms which ferment lactic acid of the first experiment were able to ferment lactic acid, avoiding that its accumulation inhibit growth of other ruminal microorganisms in the media with lower concentrations of lactic acid (50, 100, 150 and $200 \mathrm{mM})$.

\section{Conclusions}

Although propionic acid was not used as energy source by ruminal microorganims, differently from lactic acid, both affect bacterial metabolism. Propionic acid, and especially lactic acid, at high concentrations, inhibits growth of some ruminal bacterial species.

\section{References}

BELLO, M.G.D.; ESCOBAR, A. Rumen manipulation for improved utilization of tropical forages. Animal Feed Science Technology, v.69, p.91-102, 1997.

CASTILlO, C.; BENEDITO, J.L.; MÉNDEZ,J. et al. Organic acids as a substitute for monensin in diets for beef cattle. Animal Feed Science and Technology, v.115, p.101-116, 2004.

DIJKSTRA, J.; FORBES, J.M.; FRANCE, J. Quantitative aspects of ruminant digestion and metabolism. 2.ed. Cambridge: CABI Publishing, 2005. 734p. 
FERREIRA, L.S.; BITTAR, C.M.M.; SANTOS, V.P. et al. Efeito da adição de butirato de sódio, propinato de cálcio ou monensina sódica no concentrado inicial sobre parâmetros ruminais e desenvolvimento do rúmen de bezerros leiteiros. Revista Brasileira de Zootecnia, v.38, n.11, p.2238-2246, 2009.

HOBSON, P.N.; STERWART, C.S. The rumen microbial ecosystem. 2.ed. London. 1997. 719p.

KOZLOSKI, V.K. Bioquímica dos ruminantes. Santa Maria: UFSM, 2002. 140p.

LANA, R.P.; RUSSEL, J.B.; VAN AMBURGH, M.E. The role of pH in regulating ruminal methane and ammonia production. Journal Animal of Science, v.76, p.2190-2196, 1998.

MELO, M.R. Produção de ácido propiônico em soro de leite por bactéria do rúmen bovino. 2007. 54f. Dissertação (Mestrado em Zootecnia) - Universidade Federal de Viçosa, 2007, Viçosa, MG.

MARTIN, S.A. Manipulation of ruminal fermentation with organic acids: a review. Journal of Animal Science, v.76, p.3123-3132, 1998.

OWENS, F.N. Fermentácion ruminal. In: CHURCH, D.C (Ed.). El ruminante fisiología digestive y nutrición. 4.ed. Zaragoza: Acríbia, 1993. 641p.
PRIEGO, A.; SUTHERLAND, T.M. The effect of propionic acids on pattern of ruminal fermentation. Tropical Animal Production, v.2, n.2, p.189-194, 1977.

RUSSELL, J.M.; STROBEL, H.J. Effects of additives on in vitro ruminal fermentation: a comparison of monensin and bacitracin, another gram-positive antibiotic. Journal of Animal Science, v.66, n.2, p.552-558, 1989.

RUSSELL, J.M. Rumen microbiology and its role in ruminant nutrition. New York: Ithaca, 2002. 119p.

RUSSELL, J.M.; WILSON, D.B. Why are ruminal cellulolytic bacteria unable to digest cellulose at low pH? Journal of Dairy Science, v.79, p.1503-1509, 1996.

RUSSELL, J.M.; HINO, T. Regulation of lactate production in Streptococcus bovis: A Spiraling effect that contributes to rumen acidosis. Journal of Dairy Science, v.68, p.1212-1721, 1985.

WEBEL, M.L.; LANA, R.P.; BORGES, A.C. et al. Efeito do $\mathrm{pH}$ in vitro sobre a resistência de bactéiras do rúmen à perda de potássio intracelular e efeito do pH e de ionóforos sobre a produção de amônia e proteína microbiana. Arquivo Brasileiro de Medicina Veterinária e Zootecnia, v.57, n.6, p.777-783, 2005. 